\title{
PENDIDIKAN KARAKTER ISLAMI DAN PEMBERDAYAAN KEARIFAN LOKAL DALAM PAUD
}

\author{
Syamsul Bachri Thalib \\ Fakultas Psikologi Universitas Negeri Makassar \\ Email: syamsulbt@yahoo.com
}

\begin{abstract}
Character education as an effort designed to systematically and continuously to form the personality of students based on noble norms which are upheld highly by society. Cultural factors and social environment including religious values, norms, socio-cultural changes, and the goals or expectations to be achieved which reflected in the social interaction relationship is potentially have an effect and contribution to the character development of students. Therefore, the family-based and the local Islamic wisdom character education should become the main focus from the beginning or from the early childhood. Character values that can be developed include obedient attitudes and behaviors in implementing the values of religion, honesty, discipline, environmental care, social care, and values oriented to the development of noble character. Teachers and education personnels play an important role in stimulating the development of the character and personality of early childhood.
\end{abstract}

Key words: Character education, local wisdom

\begin{abstract}
Abstrak
Pendidikan karakter sebagai upaya yang dirancang secara sistematis dan berkesinambungan untuk membentuk kepribadian peserta didik berdasarkan normanorma luhur yang dijunjung tinggi masyarakat. Faktor budaya dan lingkungan sosial termasuk nilai-nilai agama, norma-norma, perubahan-perubahan sosiokultural, dan tujuan atau harapan yang ingin dicapai yang terefleksi dalam hubungan interaksi sosial adalah potensial berpengaruh dan memberikan kontribusi terhadap pengembangan karakter peserta didik. Oleh karena itu, pendidikan karakter berbasis keluarga dan kearifan lokal yang islami seyogiyanya menjadi fokus utama sejak awal atau sejak anak usia dini. Nilainilai karakter yang dapat dikembangkan mencakup sikap dan perilaku yang patuh dalam melaksanakan ajaran agama, jujur, disiplin, peduli lingkungan, peduli sosial, dan nilainalai yang berorientasi pada pengembangan akhlak mulia. Pendidik dan tenaga kependidikan berperan penting dalam menstimulasi pengembangan karakter dan kepribadian anak usia dini.
\end{abstract}

Kata-kata kunci: Pendidikan karakter, kearifan lokal

$\mathrm{U}$ sia dini (0 - 6 tahun) merupakan masa penting dalam pembentukan pribadi seorang anak, baik dari segi intelektual, kepribadian, kesehatan, maupun dari segi psikososialnya. Perkembangan yang baik ditentukan oleh beberapa aspek di antaranya adalah adanya dukungan kesehatan, gizi, dan stimulasi psikososial yang cukup pada saat pertumbuhan dan perkembangan di usia dini. Stimulasi psikososial dan pendidikan usia dini diberikan melalui berbagai pusat pendidikan pra sekolah seperti kelompok bermain dan taman kanak-kanak. Namun umumnya pelayanan ini sering tidak seragam, terkotakkotak dan tidak terintegrasi, sehingga sulit untuk memberikan kualitas kesehatan dan 
pendidikan yang optimal. Apatah lagi cakupan pelayanan pendidikan usia dini pada anak di Indonesia masih sangat kurang. Diperkirakan hanya sekitar 27 persen anak usia di bawah 0-6 tahun yang mendapatkan sejenis pelayanan pendidikan anak usia dini ini.

Keluarga merupakan pendukung utama nilai-nilai kearifan lokal terutama dalam pengasuhan anak. Dalam keluarga, anak merupakan pusat perhatian, bahkan semenjak masih dalam kandungan. Oleh karena itu, orang tua diharapkan mendapatkan model pengasuhan yang tepat. Pengelolaan keluarga termasuk gaya atau model-model pengasuhan orangtua memberikan kontribusi terhadap perkembangan anak. Pengasuhan orangtua secara efektif memerlukan suatu keterampilan untuk pertumbuhan dan perkembangan anak. Kelemahan dalam salah satu atau lebih dari keterampilan yang diperlukan dalam pengelolaan keluarga akan berdampak negatif bagi perkembangan anak. Gangguan dan kekacauan dalam pengelolaan keluarga merupakan variabel mediasi utama perilaku kekerasan dan psikopatologis (Patterson, 1982).

\section{Konsep Pengasuhan secara Umum}

Keluarga merupakan lingkungan sosial yang pertama dan terutama bagi anak. Proses interaksi antara anak dengan orang-orang di sekitarnya, terutama dengan orangtuanya, yaitu ibu dan ayah mulai di lakukan dalam lingkungan keluarga. Melalui proses interaksi antara anak dan orangtua terbentuklah sikapsikap dan perilaku pada masing-masing pihak, anak mempunyai gambaran tertentu mengenai orangtua, demikian pula sebaliknya orangtua akan mempunyai gambaran tertentu mengenai anaknya.

Pengasuhan orangtua dipengaruhi oleh model interaksi orangtua (ayah-ibu) dan anak, kondisi keluarga dan harapan orangtua, keadaan sosial ekonomi, pendidikan dan pekerjaan orangtua, besar-kecilnya anggota keluarga dan karakteristik anak (Kuczynski et al., 1997). Di samping itu, pengasuhan terjadi dalam konteks yang lebih luas daripada unit keluarga termasuk lingkungan geografis dan faktor sosial budaya seperti kepercayaan, nilainilai dan norma-norma yang berlaku dalam masyarakat sehingga terdapat berbagai variasi bentuk transmisi dan internalisasi nilai-nilai (Ancok, 1996; Garbarino et al., 1997; Goodnow, 1997).

Interaksi antara anak dengan orangtua terjadi dalam praktek pengasuhan orangtua. Pengasuhan orangtua dalam keluarga tidak hanya mencakup upaya orangtua memelihara dan melindungi anak, tetapi mencakup aktivitas yang kompleks yang menggambarkan peran orangtua dalam mempengaruhi perkembangan anak yang dilakukan baik secara individual maupun kelompok termasuk upaya mengontrol dan mensosialisasikan anak (Baumrind (1971).

Pengasuhan orangtua sebagai suatu mekanisme yang secara langsung membantu anak mencapai tujuan sosialisasi dan secara tidak langsung mempengaruhi internalisasi nilai-nilai sehingga anak lebih terbuka terhadap upaya sosialisasi melalui berbagai bentuk kompetensi interaksi sosial. Pengasuhan orangtua memberikan kesempatan kepada anak untuk memperoleh berbagai bentuk keterampilan melalui eksplanasi, dorongan dan diskusi serta adanya pengakuan dari pihak orangtua (Darling \& Steinberg, dalam Grusec, 1997).

Pengasuhan orangtua merupakan suatu proses sosial yang kompleks yang melibatkan lebih dari sekedar upaya ibu dan ayah menjaga keselamatan anak, memberi makan dan minum, dan memberi pertolongan pada saat dibutuhkan terhadap anak dan remaja. Pengasuhan adalah istilah yang merangkum sejumlah perilaku yang berkaitan dengan kelangsungan hidup, reproduksi, perawatan, dan sosialisasi. Peran orangtua terhadap perkembangan anak dijelaskan oleh Darling (1998) bahwa pengasuhan orangtua memberikan kontribusi utama terhadap proses sosialisasi anak, independensi, kematangan, kontrol diri, kemandirian, keingintahuan, persahabatan, orientasi berprestasi, dan nilainilai prososial. 
Pengasuhan orangtua, sebagai proses interaktif antar anggota keluarga, berhubungan dengan keterampilan dalam menerapkan pengawasan (monitoring) penggunaan disiplin dan hukuman yang efektif, pemberian dorongan atau penguatan yang mendukung perkembangan keterampilan prososial dan keterampilan pemecahan masalah (Patterson, 1997). Pada dasarnya aspek pemantauan orangtua (parental monitoring) menggambarkan adanya kontrol dan harapan orangtua terhadap keberadaan dan aktivitas anak.

Pengawasan terhadap anak dapat dilakukan secara langsung maupun secara tidak langsung. Pemantauan langsung dilakukan dengan mengamati secara aktif keberadaan dan aktivitas anak setiap saat atau secara periodik di sekolah maupun di luar sekolah. Pemantauan secara tidak langsung dapat dilakukan secara efektif melalui upaya saling berbagi informasi dan pengalaman. Pemantauan secara tidak langsung ini memberikan kontribusi yang signifikan terhadap perkembangan kelekatan emosional antar anggota keluarga. Pertukaran informasi dan pengalaman dapat menciptakan dan mengembangkan rasa kasih sayang dan kehangatan antar anggota keluarga. Keterlibatan anak dalam pertukaran infromasi dan pengalaman merupakan faktor penting dalam memperkenalkan secara efektif tentang pentingnya nilai-nilai, keterampilan serta berbagai jenis perilaku prososial.

Penggunaan hukuman dan disiplin secara konsisten serta bantuan pemecahan masalah merupakan aspek penting dalam proses kepembimbingan dan pengasuhan. Patterson dan Stouthamer-Loeber (1984) mengasumsikan bahwa orangtua yang tidak efektif dalam memantau permasalahan anak, cenderung menjadi tidak efektif dalam berbagai disiplin yang digunakan sebagaimana halnya tidak efektifnya dalam pemecahan masalah keluarga dan kurangnya penguatan terhadap perilaku positif untuk perkembangan keterampilan prososial anak. Orangtua yang tidak konsisten dalam penerapan disiplin, penggunaan hukuman fisik, daya kritis yang berlebihan dan sikap bermusuhan mengandung resiko bagi permasalahan perilaku remaja.

Orangtua yang menggunakan disiplin, hukuman dan kontrol yang ketat cenderung merasa kurang puas, menunjukkan afek negatif dan memandang pengasuhan sebagai hal yang sulit. Patterson dan Fleischman (dalam Patterson, 1982) berdasar studi empiris menyimpulkan bahwa pada umumnya orangtua remaja antisosial lebih sering memberikan hukuman, perintah yang tidak jelas atau sulit dimengerti oleh remaja, mudah marah, tidak sabar, dan menunjukkan sikap yang tidak menyenangkan dibanding pemberian penguatan terhadap perilaku positif remaja. Hal ini dimungkinkan karena remaja antisosial lebih sering melakukan penyimpangan perilaku yang kemudian direspon oleh orangtua mereka dengan omelan, ancaman, pemukulan dan bentuk-bentuk perilaku kekerasan lainnya. Sesungguhnya jika terjadi konflik dalam pengelolaan keluarga khususnya dalam menghadapi permasalahan perilaku remaja, maka diperlukan suatu solusi berupa komunikasi antar pribadi yang efektif, pengakuan melalui penguatan positif, spesifikasi secara jelas perubahan perilaku yang diharapkan dan keterampilan mengatasi permasalahan melalui teknik curah pendapat (Webster-Stratton, 1998).

Secara umum, Darling (1998) mengidentifikasi 2 elemen penting dalam praktek pengasuhan, yakni keresponsifan dan kontrol orangtua terhadap anak. Keresponsifan mengacu pada kehangatan dan dukungan orangtua dalam mengembangkan individualitas, regulasi diri, penyesuaian diri, kebutuhan-kebutuhan spesifik, dan tuntutan anak. Selanjutnya, tuntutan dan kontrol orangtua mengacu pada aspek pengawasan atau kontrol dan penerapan disiplin yang konsisten dalam upaya mengarahkan anak sebagai bagian integratif keluarga.

Mengacu pada serangkaian hasil studi, Baumrind (1971) menggolongkan modelmodel pengasuhan orangtua atas tiga kategori utama, yaitu: model pengasuhan otoritarian, model pengasuhan otoritatif dan model pengasuhan permisif. 
Pengasuhan dengan model otoritarian menunjukkan ciri-ciri: orangtua cenderung melakukan kontrol secara ketat dengan standar perilaku yang ditentukan oleh orangtua tanpa kompromi dan negosiasi dengan anak, disiplin yang kaku, cenderung menyandarkan hukuman fisik terhadap pelanggaran, orangtua tidak mendorong anak, cenderung lebih agresif dalam mengatasi konflik, kurang menunjukkan kasih sayang dan kehangatan dalam proses interaksi. Konsekuensinya, anak menjadi tergantung terhadap orang lain, kurang independen dan tidak menunjukkan tanggungjawab sosial (Baumrind, 1971), dan dapat menghambat perkembangan kompetensi sosial, dan munculnya problem perilaku dan psikologis seperti kecemasan, depresi dan percaya diri yang rendah (Moore, 1992).

Pengasuhan dengan model otoritatif menunjukkan ciri-ciri: orangtua mengarahkan, lebih terbuka, memberikan pertimbangan dan penjelasan yang rasional tentang kebijakan yang akan dilaksanakan, orangtua memberikan otonomi kepada anak tetapi juga dengan disiplin, orangtua memberikan kebebasan tetapi juga mengontrolnya, saling memberi dan menerima antara anak dan orangtua, orangtua menunjukkan kehangatan dan komunikaasi yang baik, namun tetap konsisten dalam pernyataan-pernyataan dan tindakan. Konsekuensinya, remaja dengan orangtua autoritatif menunjukkan tanggungjawab sosial yang tinggi, lebih independen, memungkinkan berkembangnya kompetensi sosial remaja, mencegah problem perilaku, dan gangguan psikologis lainnya.

Model pengasuhan otoritatif merujuk pada istilah model pengasuhan demokratis, sebagaimana dikemukakan oleh ahli-ahli psikologi pegasuhan lainnya. Model pengasuhan yang tergolong demokratis berorientasi pada kontrol positif, disiplin positif, konsistensi dan sifat tegas dalam batasbatas tertentu. Di samping itu, model pengasuhan demokratis sarat dengan penalaran, disiplin, dan ketegasan teapi menunjukkan kehangatan, fleksibilitas, empati dan saling pengaertian antara orangtua dengan anak.
Pengasuhan demokratis memberikan kesempatan kepada anak untuk berperanserta dalam berbaagi aktivitas, menaruh perhatian terhadap pandangan dan perbedaan individal anak, dan fleksibel terhadap aturan-aturan yang telah disepakati bersama. Di samping itu, pengasuhan demokratis juga memberikan dorongan, membantu anak dalam membuat keputusan, dan memecahkan masalahnya sendiri, ada kesempatan untuk mengembangkan pemikiran, kreativitas, tanggungjawab, percaya diri, kontrol diri, dan konsep diri yang positif terhadap diri sendiri dan orang lain (Johnson, 2002; Lerner et al., 1998; Niolon, 2002; Watenburger, 1994).

Model pengasuhan permisif menunjukkan ciri-ciri: tidak ada kontrol dari orangtua, memberikan kebebasan terhadap harapan-harapan dan tindakan anak, serba boleh terhadap perilaku anak, tidak konsisten dalam menerapkan ketentuan dan disiplin, orangtua tidak mendorong anak untuk mengikuti standar yang ada, kurang melakukan kontrol dan cenderung memanjakan anak. Konsekuensinya, remaja menunjukkan kontrol diri, harga diri dan konsep diri negatif, tanggungjawab sosial yang rendah, dan gangguan penyesuaian diri (Moore, 1992; Niolon, 2002).

Mengacu pada pendapat Baumrind tentang model pengasuhan, McMahon et al. (1995) mengklasifikasikan model pengasuhan atas tiga kategori utama, yaitu model diktatorial, otoritatif, dan permisif. Pada model diktatorial, orangtua menunjukkan sikap yang kaku, tidak fleksibel, tidak percaya bahwa anak-anak mereka dapat membuat keputusan sendiri tentang sesuatu yang akan dilakukannya. Konsekuensinya, anak tidak dapat mengambil suatu keputusan yang berguna baginya dan sering mengalami kesulitan dalam berhubungan dengan anak lainnya. Jadi model diktatorial pada prinsipnya sama dengan istilah otoritarian menurut model Baumrind.

Model pengasuhan yang permisif cenderung mengabaikan anak, tidak konsisten dalam menerapkan aturan, memberikan perlindungan dan aksih sayang yang 
berlebihan. Sebagai akibatnya, anak cenderung tidak banyak belajar tentang perilaku yang tidak dapat diterima (unacceptable behavior), tidak mempunyai disiplin diri, cenderung kurang percaya diri, impulsif, dan sulit mengambil keputusan tentang dirinya sendiri

Model-model pengasuhan menurut Baumrind (1971) dan McMahon et al. (1995), jika diperhatikan secara lebih cermat, maka di antara mereka menunjukkan adanya persamaan dari masing-masing jenis model pengasuhan. Perbedaannnya hanya pada istilah yang digunakan. Baumrind menggunakan istilah otoritarian, sedangkan McMahon et al. menggunakan istilah diktatorial. Kedua model pengasuhan lainnya menggunakan istilah yang sama, yaitu model otoritatif dan permisif. Namun, istilah praktek pengasuhan yang digunakan oleh Patterson (1982) serta Patterson dan Stouthamer-Loeber (1984) lebih menekankan isi mengenai keterampilan dalam pengasuhan, sedangkan model pengasuhan sebagaimana digunakan oleh Baumrind lebih menggambarkan konteks pengasuhan (Darling dan Steinberg, dalam Grusec, 1997). Jadi, model-model pengasuhan menurut kategori Baumrind tampaknya hanya sebagai suatu upaya memahami bagaimana kecenderungan orangtua dalam mengasuh anak. Ini berarti pula bahwa tidak ada orangtua yang $100 \%$ bersifat otoritarian, permisif atau otoritatif. Model-model pengasuhan tersebut pada dasarnya mencakup pula isi (content) dalam keterampilan pengasuhan termasuk pengawasan, disiplin, ganjaran (hukuman dan hadiah), dan pemecahan masalah.

\section{Konsep Pengasuhan Berdasarkan Kearifan Lokal}

Keluarga adalah pendukung nilai-nilai kearifan lokal terutama dalam pengasuhan anak karena anak merupakan pusat perhatian keluarga, bahkan semenjak masih dalam kandungan. Setiap kelompok etnik di Indonesia mempunyai ajaran, nasehat atau petuah mengenai bagaimana mengasuh, merawat dan mendidik anak.

Bronfenbrenner (dalam Reaves, 1999) secara eksplisit memprediksi bahwa perbedaan status sosial ekonomi, rasial, kelompok etnis, dan lingkungan budaya secara umum mempengaruhi praktek pengasuhan. Kondisi ekonomi keluarga berhubungan secara langsung maupun tidak langsung dengan pemenuhan kebutuhan fisik dan psikologis anak. Orangtua yang mengalami tekanan ekonomi cenderung lebih mudah putus asa dan kehilangan harapan, kecemasan, depresi dan sifat lekas marah. Keadaan ini menyebabkan orangtua tidak konsisten dalam menerapkan disiplin dan hukuman, cenderung menerapkan hukuman fisik, bersifat unilateral atau mendominasi dan mengontrol anak secara berlebihan. Bahkan kesulitan finansial cenderung menimbulkan ekspresi agresi (McLoyds, dalam Reaves, 1999).

Selanjutnya berdasar pada perbedaan individual dan orientasi budaya, Reis dan Wheeler (dalam Taylor et al., 1994) memprediksi bahwa individu yang berasal dari lingkungan budaya individualistik seperti AS, kurang menunjukkan interaksi kelompok dibanding indiividu yang berasal dari latar budaya kolektif seperti Hongkong, Jordan, dan Indonesia. Budaya individualistik lebih menekankan pada kebutuhan, tujuan atau keinginan pribadi dan individu, sedangkan budaya kolektif lebih menekankan tujuan kelompok dan keharmonisan, kohesi dan kerjasama (Matsumoto, 1996). Keadaan ini menunjukkan bahwa faktor budaya dan lingkungan sosial termasuk agama dan kepercayaan, norma-norma, perubahanperubahan sosiokultural, dan tujuan atau harapan yang ingin dicapai yang terefleksi dalam hubungan interaksi orangtua dan remaja adalah potensial berpengaruh dan memberikan kontribusi terhadap pengasuhan orangtua. Sebagai contoh, masyarakat Jawa yang mempunyai nilai-nilai sosial yang tinggi seperti nilai rukun (hubungan sosial yang harmonis dan positif), gotong royong (interdependensi), tepaseliro (nilai tenggang rasa yang mengajarkan bagaimana seseorang memahami perasaan orang lain sehingga perilakunya tidak mengusik orang lain), dan prihatin sebagai nilai yang mengajarkan bagaimana seseorang bersikap sabar dan tidak mudah putus asa dalam menghadapi sesuatu 
terutama sesuatu yang dirasa tidak enak (aversive) akan membimbing kehidupan mereka termasuk dalam praktek pengasuhan (Wimbarti, 2000; 2001).

Selanjutnya Ekowarni menjelaskan variasi kearifan lokal dalam mendidik dan mengasuh anak. Masyarakat Batak Mandailing sangat menjunjung tinggi falsafah 3H, yaitu hamoroan (kekayaan), hagabeon (kehormatan), hasangapon (kebahagian). Falsafah tersebut menjadi acuan dalam pola pendidikan, terutama terhadap anak laki-laki yang dianggap sumber kebahagian dan penerus marga. Oleh karena itu, masyarakat Batak menganut sistem patrilineal, setelah menikah seorang istri mengikuti marga suaminya dan seorang anak perempuan tidak memperoleh harta peninggalan orang tuanya. Sistem dalihan na tolu menjadi tatanan yang mengatur perilaku termasuk tatanan perilaku anak perempuan. Dengan sistem dalihan na tolu, konflik atau pertikaian keluarga dapat diselesaikan, juga mengatur kedudukan seseorang dalam posisi yang berbeda tergantung dengan siapa berhadapan.

Budaya Minangkabau menganut tatanan yang mengatur nilai masyarakat Minangkabau adalah adat dan syara, kewajiban menjaga kepentingan keluarga. Peran ninik-mamak sangat berpengaruh terutama dalam menjaga terjadinya pelanggaran nilai - nilai keluarga maupun agama. Sistem kekerabatan bersifat matrilineal dan matriarcht, posisi perempuan Minangkabau sangat kuat, pihak perempuan menjemput pihak laki-laki dengan membawa jumlah uang dan barang hantaran. Perempuan Minangkabau memiliki banyak kewenangan keseharian masih bergantung pada peran ninik - mamak ( Alim, 1986 ).

Masyarakat Lampung menganut nilai piil Pesenggiri atau watak utama dalam mendidik dan mengasuh anak. Watak utama yang diharapkan adalah (a) piil Penggiri memiliki harga diri, (b) Juluk adek memiliki gelar, (c) Nemui Nyimah bersikap terbuka, (d) Nengah Nyapur hidup bermasyarakat, (e) Sangkai Sambayan tolong - menolong. Upacara adat yang dilakukan terhadap anak adalah (a) Upacara Tecahan, dilaksanakan ketika anak berusia tujuh hari dengan ritual (memberi nama, mencukur rambut, akikah dimana kerabat dan keluarga membaca shalawat Nabi Muhammad S.A.W dan doa bagi keselamatan anak), (b) Upacara Turun Mandi, dilakukan ketika anak berusia dua tahun sebagai keyakinan bahwa sungai adalah bagian dari alam yang sangat penting bagi kehidupan anak sebagai tempat bermain atau mendapatkan air untuk berbagai keperluan hidup. Dengan melakukan ritual, anak diantar (diarak) ke sungai diiringi berbagai tetabuhan dAn sesaji. Nenek si anak melakukan upacara memperkenalkan anak kepada penunggu sungai agar tidak mengganggu atau mencelakai anak.

Tradisi Melayu yang patut disebut "anak bertual" ialah anak yang menjadi"orang", yakni menjadi manusia yang sempurna lahiriah dan batiniahnya. Anak yang menjadi " Orang" senantiasa diharapkan serta diidam-idamkan oleh setiap keluarga Melayu, karena akan membawa "tuah" bagi orang tua dan kaum kerabatnya, tetapi juga bangsa dan negaranya. Kewajiban dan tanggung jawab orang tua terhadap anaknya disebut "hutang orang tua"kepada anaknya. Pokok-pokok kewajiban dan tanggungjawab antara lain adalah (a) "Hutang bela dengan pelihara "ialah kewajiban orang tua untuk menyempurnakan pemeliharaan terhadap anak supaya kuat dan sehat, baik jasmani maupun rohaninya, (b) " Hutang tunjuk dengan ajar" merupakan kewajiban orangtua menyempurnakan pemeliharaan anaknya dengan mendidik dan mengajarkan segala ilmu pengetahuan, supaya anak menjadi cerdas dan berpengetahuan luas, (c) "hutang tuang dengan isi" adalah kewajiban orangtua untuk melengkapi ilmu pengetahuan anaknya dengan menanamkan nilai-nilai luhur yang bersumber dari ajaran agama, adat-istiadat, tradisi yang hidup di dalam masyarakat. Dengan demikian, anak tersebut tidak tercabut dari akar budaya bangsanya kokoh kepribadiannya.

Masyarakat Jawa mengasuh dan mendidik anak-anak untuk dapat memenuhi harapan agar anak-anak memiliki berbagai 
sifat utama, antara lain berbudi luhur, rukun, temen, tresna, dan berbagai waktu yang menggambarkan manusia yang beriman dan bertaqwa kepada Tuhan Yang Maha Esa, cerdas, sehat, dan berahlak mulia. Besarnya harapan orangtua pada anak, diungkapkan dalam berbagai upacara yang bermakna simbolik (a) Pemulasaraan ari-ari (plasenta), dilakukan oleh ayah si bayi dengan mencuci sampai bersih, memasukkan dalam guci beserta kelengkapannya dan menahan di tempat yang layak di sudut halaman. Di atas tanah diberi lampu minyak tanah selama empat puluh hari, (b) Selapanan, ialah upacara ketika bayi berusia 35 hari (selapan), (c) tedhak siten (turun tanah), ritual upacara ini dilakukan ketika anak berusia 7x35 hari (tujuh lapan). Kelengkapan ritual menggambarkan kewajiban orang tua membimbing anaknya untuk menghadapi berbagai masalah hidup serta mematuhi aturan-aturan atau nilai-nilai yang dijunjung tinggi oleh masyarakat Jawa.

Selanjutnya masyarakat Bugis Makassar menjunjung tinggi nilai-nilai panngaderreng (sistem norma dan aturanaturan adat) yang berdasar pada konsep siri'. Berdasar konsep siri', masyarakat Bugis Makassar yang memuliakan hal-hal yang menyangkut soal-soal keagamaan, kesetiaan memegang janji dan persahabatan, saling memaafkan, saling mengingatkan untuk berbuat kebajikan, tak segan saling memberi pertolongan/pengorbanan, dan memeliharan ketertiban adat perkawinan (Mattulada, 1985).

Nilai malu dalam kandungan siri'
menurut Marzuki (1995) menggugah
seseorang agar tidak melakukan pelanggaran
ade', sementara nilai harga diri atau martabat
menuntut seseorang untuk selalu patuh dan
hormat pada kaidah-kaidah ade' (hukum). Hal
ini terungkap dalam petuah-petuah lisan
(paseng, pasang), antara lain sirikaji tau
(hanya siri' maka kita dinamakan manusia),
sirikaji tojeng (hanya siri'-lah yang benar),
sirikaji nipammatangngang rilino (hanya
karena siri', maka kita hidup di dunia).
Konsep siri' dalam praktek pengasuhan
terungkap dalam paseng (petuah, nasehat,
amanat) yaitu rioloi napatiroang, ritengngai

naparaga-raga, rimunriwi napa'ampiri (dari depan menjadi suri teladan, di tengah aktif memberikan bantuan dan dari belakang aktif memberi dukungan dan dorongan).

Nilai-nilai fundamental siri' yang relevan dengan pengasuhan dan kepembimbingan di sekolah, mencakup semangat sipakatau, pacce, parakai sirimu, cappak lilah, rupannamitaue dek naulle ripinra, sipatuo sipatokkong, sipamali siparappe (Abdullah, 1997). Semangat sipakatau bermakna saling menghargai dan menghormati sesama manusia. Nilai budaya ini memancarkan penghargaan dan keserasian hubungan dengan orang lain. Pacce bermakna kesetiakawanan terhadap sesama manusia. Sifat kemanusiaan terefleksi dari paccei pammaikku yang berarti merasa ikut menderita atau merasakan kesulitan orang lain. Parakai sirimu merefleksikan perasaan tanggungjawab dan pengendalian diri. Siri berfungsi mengontrol diri dari perbuatan yang bertentangan dengan nilai-nilai moral dan agama. Falsafah cappak lilah (ujung lidah) bermakna keterampilan berkomunikasi dan berdialog dengan penuh keterbukaan dan tutur kata yang santun yang berimplikasi pada keharmonisan sosial. Rupannamitaue dek naulle ripinra (hanya wajah manusia yang tidak bisa diubah) bermakna percaya diri dan sikap optimisme terhadap peluang terjadinya perubahan pada diri manusia ke arah yang lebih baik. Sipatuo sipatokkong, sipamali siparappe (saling mengembangkan dan saling menghidupkan) yang berimplikasi pada upaya saling membantu dan memahami orang lain. Pajjama (usaha dan kerja keras) mengandung makna kemandirian, sikap optimis dan dinamis menghadapi masa depan disertai dengan ketekunan dan kerja keras. Getteng (ketegasan prinsip) mengandung makna kepercayaan diri, keberanian menanggung resiko dan adanya kesesuaian antara perkataan dan tindakan.

Pola pengasuhan masyarakat Bugis makassar lebih dominan dilakukan oleh orangtua. Secara umum pola pengasuhan disesuaikan dengan tingkat usia, jenis kelamin, urutan anak dalam keluarga, nilai-nilai budaya, dan agama. Pada masa bayi dan balita, anak 
diperlakukan secara otoritarian sesuai dengan kondisi fisik dan psikologisnya. Penanaman nilai budaya ditanamkans ejak usia balita, antara lain melalui elong (kelong). Melalui elong ditanamkan rasa kasihsayang, saling menghormati, menghargai, saling mengingatkan (sipakatau, sipakalebbi, sipakainge. Menanam adat dimaksudkan agar seseorang meletakkan sendi-sendi tatanam amsyaraakat yang dikernal dengan toddopuli (berpendirian kokoh), kuntutojeng (menanamkan kepercayaanm dan dapat dipercaya, sipakatau (saling menghormati). Orang yang tidak mampu menjaga dan membela kehormatan diri dan keluarga akan mendapat julukan kawe-kawe atau calabai. Seseorang yang bersifat penakut atau pengecut diberi julukan ballorang, orang yang tidak punya rasa malu disebut tena siri'na.

Selanjutnya cara-cara praktis dalam membimbing anak yang relevan dengan budaya siri' termasuk sikap positif, mengembangkan rasa percaya diri, menyediakan pilihan bagi anak-anak, dan bekerjasama dengan anak-anak. perlihatkan contoh yang baik, dan perlihatkan perasaan cinta. Perbuatlah hal-hal positif. Catatlah halhal positif yang Anda katakan kepada anakanak, catatl;ah berapa kali sehari Anda mengatakan "tidak, jangan, atau berhenti", Anda tertarik mengajarkan perilaku yang berharga, seperti tanggungjawab, kejujuran, kerjasama, dan saling membagi. Bagaimana Anda mengerjakan apa yang Anda khotbahkan? Bagaimana Anda memperlihatkan rasa cinta Anda kepada anggota keluarga, agar anak melihat hal itu sebagai contoh yang baik? Buatlah daftar halhal yang Anda perlihatkan selama sehari. Ubah kalimat-kalimat negatif, seperti jangan menyeret pakaianmu di tempat yang kotor, jangan meneriaki saya, jangan berbicara pada waktu mulutmu penuh makanan, dan semacamnya, menjadi kalimat-kalimat positif dengan mengatakan atau memperlihatkan halhal positif. Bekerjasama dengan anak-anak berarti menyediakan barang-barang yang sesuai dengan usianya untuk digunakan. Di samping itu, tradisi dongeng dan permainan anak merupakan hal penting untuk perkembangan watak anak. Dongeng dan permainan mengandung ajaran moral dan budi pekerti luhur, tetapi anak perlu didampingi dalam mengungkap makna atau esensi dalam dongeng atau permainan tersebut. Si kancil dalam berbagai cerita mengandung ajaran mengenai watak, kecerdikan, balas budi, kerukunan, persatuan akan mengalahkan kesewenangan, dan sebagainya. Juga, cerita tentang timun mas, bawang merah bawang putih, malin kundang, dan ak belalang merupakan cerita yang disukai anak-anak.

Selanjutnya, uraian berikut ini menggambarkan hasil penelitian tentang pengetahuan, sikap, dan perilaku orangtua terhadap anak usia dini (Thalib, dkk, 2007).

\section{a. Pengetahuan tentang anak usia dini}

Pandangan responden tentang anak ideal cukup bervariasi, sebagian besar menyatakan bahwa anak ideal dari aspek pendidikan adalah anak yang mempunyai tingkat pendidikan yang memadai atau harus menempuh pendidikan formal serta harus dibina mulai dari umur $0-6$ tahun dan $6-12$ tahun. Pengetahuan tentang anak ideal dari aspek agama adalah anak yang patuh, alim, bermoral, berperilaku baik, taat pada orang tua, berbakti pada nusa, bangsa dan agama. Kemudian dari aspek kesehatan, mereka berpandangan bahwa anak harus sehat dengan cara memperhatikan gizinya.

Berdasar perbedaan jender, masyarakat tidak mempersoalkan perbedaan anak-anak laki-laki dan perempuan, hanya saja mereka menginginkan dalam suatu keluarga dianggap lebih lengkap sekiranya ada anak laki-laki dan perempuan. Menurut mereka, keadaan ini akan sangat membantu dalam menjalankan tugas keseharian, terutama pekerjaan sebagai petani atau pedagang. Harapannya, anak laki-laki membantu ayahnya untuk bertani, berkebun, sedangkan anak perempuan membantu ibunya dalam urusan rumah tangga. Menurut mereka, secara fisik anak laki-laki lebih kuat dari perempuan, dan anak perempuan dianggap lebih sesuai untuk membantu ibunya mengurus rumah tangga. 
Pandangan masyarakat tentang kondisi mental anak seperti yang mengalami gangguan tingkah laku, cacat fisik, anak cerdas, pada dasarnya diberikan kesempatan sama dengan anak yang normal. mereka sama diberikan pendidikan yang sama layaknya dengan anak yang normal, mereka harus didik sebab itu juga pemberian dari yang Maha Kuasa,

\section{b. Sikap orangtua terhadap anak usia dini}

Sikap masyarakat terhadap PAUD pada dasarnya hampir sama, yaitu mereka menginginkan anaknya untuk memperoleh pendidikan sesuai dengan kemampuan anak dan kemampuan ekonomi orang tuanya. Masyarakat merespon positif pentingnya pendidikan anak usia dini. Hanya saja, mereka juga realistis dalam kaitannya dengan kondisi ekonomi mereka. Bahkan sebagian masyarakat menyatakan anak-anak mereka mesti disekolahkan, bagaimanapun caranya. Sementara itu dari aspek agama, mereka mempunyai sikap perlunya anak-anak mereka belajar tentang agama sejak dini sebagai bekal dalam hidupnya, seperti belajar mengaji, shalat, tata krama dan sopan santun. Masyarakat menunjukkan sikap perlunya menjaga dan memelihara kesehatan anak melalui pemberian makanan dan gizi yang sehat. Sikap masyarakat terhadap pendidikan disiplin bagi anak juga bersifat positif. Pendidikan disiplin perlu ditanamkan sejak dini. Dengan demikian anak dapat hidup secara teratur, dan menghargai norma-norma yang berlaku di masyarakat. Oleh karena itu, orangtua perlu memberi contoh atau menjadi model bagi anak. Sikap mereka tentang anak sulung, tengah, dan bungsu, sebagian besar mereka menyatakan bahwa itu tidak ada perbedaan dalam memberikan perhatian, karena kedudukan anak-anak dalam keluarga sama saja, tidak boleh ada perlakuan yang berbeda.

\section{c. Kegiatan dalam pelaksanaan pendidikan anak usia dini}

Untuk mewujudkan agar anak menjadi yang ideal, maka masyarakat mengajarkan atau mengasuh anak dengan cara yang sudah berlangsung secara turun-temurun yaitu dengan terlebih dahulu mengajarkan kepada anaknya tentang hidup sopan santun, baik dari segi tutur kata maupun sifat dan tata perilaku. Dalam mewujudkan harapan mereka agar anak-anaknya menjadi anak ideal, pada dasarnya mereka menyatakan tergantung dari orang tuanya, nanti kalau orang tuanya tidak mampu, maka akan meminta bantuan kepada kerabat terdekatnya yaitu saudara, sepupu, ataupun tetangga terdekat. Satu hal yang menarik dari responden bahwa mereka mengharapkan anaknya menjadi pintar, sehingga suatu kelak dapat merantau (massompe) untuk mencari kehidupan di tempat lain. Mereka menyebutnya merantau ke kampungnya orang harus dibekali dengan kemampuan dasar yaitu pandai menghitung. Hal ini dapat dilihat dari kondisi masyarakat, dimana pemudanya banyak yang merantau ke daerah lain.

Hambatan dalam mewujudkan anakanak mereka menjadi anak ideal, menurut persepsi mereka adalah ada dua hal, yaitu faktor yang bersumber dari orang tua, dan faktor yang bersumber dari anak itu sendiri. Faktor orang tua yang kurang peduli terhadap studi lanjut anak-anak dengan alasan kurang biaya untuk memenuhi kebutuhan sekolah anaknya. Mereka sudah cukup puas kalau anak-anak mereka sudah bisa membaca, berhitung, dan membantu orang tuanya bertani dan berkebun. Mereka berpendapat bersekolah atau berkebun tujuannya sama saja, yakni memperoleh materi (uang) untuk kelangsungan hidup.

Salah satu kebisaan orangtua dalam mengasuh anak dipengaruhi oleh cara orangtua mereka secara tradisional, misalnya, anak tidak boleh turun dari rumah kalau belum cukup 40 hari. Hal ini menjadi penghambat terutama dalam hal imunisasi anak, dan sekiranya untuk mengantisipasi hal ini, lazimnya Bidan Desa langsung ke rumah-rumah orang tua balita untu melakukan imunisasi dan untuk memeriksa kesehatan anak balita. Dalam hal pengasuhan anak, yang bertugas mengasuh anak sebagian besar menyatakan adalah ibu, karena suami rata-rata mencari nafkah sehingga jarang tinggal dirumah, namun 
sebagian lagi menyatakan dua-duanya baik suami maupun ibu tergantung siapa yang mempunyai kesempatan. Jadi, ibu lebih berperan lebih banyak dalam pengasuhan anak karena ibu yang lebih banyak di rumah dan memang ibu yang berhak mengasuh anak. Untuk menyediakan makanan, ASI bagi anak 0 - 6 tahun, memandikan, mengajak bermain, bercerita atau bernyanyi, sebagian besar dilakukan oleh ibu, tugas ini lebih cenderung ibu yang melakukan karena orang tua laki-laki lebih sering keluar rumah mulai pagi hingga sore hari sehingga untuk menyediakan makanan, memandikan dan mengajak bermain tentunya dilakukan oleh ibu. Untuk penanaman disiplin untuk anak, mereka menyatakan sepakat untuk diberikan penanaman disiplin sehingga anak kelak dapat menjadi anak yang patuh dan menghargai orang lain. Penanaman disiplin anak-anak dapat dimulai sejak dini dengan cara mengatur waktu mengaji, tidur, mandi, makan, dan bermain anak, termasuk ketika mereka sudah sekolah harus disiplin. Cara menanamkan disiplin terhadap anak dilakukan dengan cara yang bervariasi, ada yang otoriter bahkan dengan tindakan tegas, ada yang demokratis terutama orang tua yang sudah memiliki tingkat pendidikan yang lebih tinggi, di samping itu orang tua dalam memberikan penanaman disiplin kepada anak dilakukan dengan cara penanaman sikap keteladanan, dan memberikan hadiah kalau berprestasi.

Anak-anak sudah diperkenalkan uang pada usia dini, rata-rata anak-anak sudah mengenal uang sejak usia 3 tahun. Orang tua dan saudara-saudara yang lebih tua biasanya memperkenalkan uang kepada anak-anak mereka. orang tua memberikan uang ketika anaknya bandel, atau ingin bepergian sehingga anak menuruti kehendak orangtua, uang menjadi pengendali perilaku anak. Kebiasaan tidur untuk anak usia $0-6$ tahun, sebagian besar ditemani orang tuanya, mereka rata-rata tidur bersama orang tua dan anak-anak mereka. Untuk mempercepat anak supaya cepat tidur biasanya orang tua menyanyikan lagu untuk anaknya atau mendongeng yang mengandung petuah atau nasehat.

\section{d. Kesehatan/gizi}

Kebiasaan atau pola makan dalam keluarga sangat tergantung pada kondisi keluarga, begitupula dalam pengaturan pola makan, tergantung dari kondisi, namun dalam hal siapa yang memutuskan atau mengatur, maka mereka menyatakan terkadang suami mereka, tentang menu makan antara anak dengan orang tua sama saja, namun untuk anak bayi mereka tentu menyediakan makanan khusus, seperti bubur, susu dan makanan yang lunak yang sesuai untuk anak.

Mengenai kebiasaan jajan bagi anak, mereka menyatakan sebagian besar anak-anak suka jajan, dan itu sudah jajan sejak kira-kira berumur 3 tahun, anak-anak jajan supaya mereka dapat bermain dengan tenang sehingga ibu atau suami dapat bekerja dan tidak diganggu lagi oleh anak-anak mereka. Pemberian ASI pertama untuk bayi dilakukan sejak bayi itu lahir, dan biasanya dihentikan ketika sudah memasuki usia 6 bulan, setelah itu dibantu dengan jenis susu lainnya atau susu formula maupun makanan tambahan (bubur). Hal ini dimaksudkan supaya anak-anak tersebut kuat secara fisik dan berkembang dengan baik. Kebiasaan masyarakat dalam merawat kesehatan anak usia dini, dilakukan baik secara tradisional maupun modern. Secara tradisional, mereka masih biasanya mengantar anak mereka ke dukun karena mereka percaya terhadap hal-hal lain yang mempengaruhi kesehatan anak. Sebagian lagi masyarakat sudah agak modern karena ketika anaknya sakit mereka langsung mengantarnya ke Bidan Desa atau Puskesmas.

Dalam hal kebersihan anak, masyarakat pada umumnya sudah memahami pentingnya aspek kebersihan, misalnya mengganti pakaian yang kotor, melarang bermain di tempat yang berdebu, atau tidak bermain ketika cuaca kurang memungkinkan. Kebiasaan para orang tua dalam merawat anaknya sehubungan dengan perkembangan kesehatan fisik, misalnya mereka menggunakan gurita, mengayun bayi, melakukan acara sunat bagi anak-anak laki-laki dan kette bagi anak perempuan. 


\section{PENUTUP}

Budaya mewariskan nila-nilai yang mengandung kearifan dalam mengasuh dan mendidik anak PAUD tidak akan mengganti peran orang tua karena kewajiban dan tanggung jawab tetap di tangan orang tua. PAUD tidak akan "mencetak " anak-anak menjadi anak yang tidak mengenal budayanya, tetapi menjadi anak yang berdiri kokoh di atas tanah tumpah darah dan budaya luhur untuk menghadapi kehidupan di era global.

Pepatah "kasih karena anak, sayang karena amanah" mengandung makna bahwa anak dikasihi karena darah dagingnya, dan disayangi karena amanah, agar kelak dapat dipertanggungjawabkan di hadapan Tuhan.

Secara kodrati, manusia menunjukkan perbedaan-perbedaan individual dalam aspek fisik, sosial, emosional, dan intelektual. Aspekaspek tersebut saling berinteraksi dalam membentuk perilaku manusia. Interaksi antara aspek-aspek tersebut diharapkan berada dalam porsi yang seimbang sehingga dalam diri manusia terdapat balancing yang sehat. Oleh karena itu, proses pembelajaran dalam PAUD seyogiyanya tidak mengabaikan pendekatan psikologis dalam upaya pengembangan kepribadian peserta didik. Pendekatan psikologis berorientasi pada pengembangan ragam kecerdasan yang mencakup kecerdasan spiritual, intelektual, sosial, dan emosional. Pendidik PAUD hendaknya mampu menunjukkan jalan alternatif untuk pemecahan masalah dalam pendidikan anak usia dini, termasuk persoalan psikologis dalam situasi pendidikan (sifat-sifat umum aktivitas manusia, sifat-sifat khas kepribadian manusia, sifat-sifat khas individu, dan perbedaanperbedaan dalam bakat). Juga persoalan psikologis mengenai manusia dalam proses pendidikan (masalah belajar, perkembangan individu, faktor dasar dan ajar, perubahan individu dalam proses belajar, pengukuran dan penilaian hasil-hasil pendidikan.

Pendidik PAUD perlu merancang sedemikian rupa ruangan kelas, alat peraga, alat permainan, kelompok belajar, metode, tugas, sehingga kecerdasan yang ada dapat dilatihkan dan dikembangkan. PAUD perlu menyediakan sarana dan kesempatan untuk mengembangkan kemampuan berinteraksi, baik berinteraksi dengan dirinya sendiri maupun berinteraksi secara sosial dengan orang-orang terdekat yang kondusif dalam pergaulan (relasi dan komunikasi), serta kemampuan untuk mengenal diri sendiri, dan mengembangkan sikap empati. Peran orangtua dalam PAUD menjadi faktor dan menjadi basis untuk kepembimbingan dan perkembangan anak. Implementasi kearifan lokal dalam PAUD merupakan langkah bijak untuk perkembangan anak, baik dari segi intelektual, sosial, dan emosional.

\section{DAFTAR RUJUKAN}

Abdullah, A.E. (1997). Beberapa unsur budaya Bugis-Makassar dan implikasinya dalam bimbingan dan konseling. Makalah (tidak diterbitkan). Purwokerto: Panitia Seminar dan Konvensi Nasional Bersama DevisiDevisi IPBI.

Abdullah, A.E. (2006). Psikologi pendidikan anak. Yogyakarta: Pustaka Timur.

Ancok, D. (1996). Cultural factors in the etiology of mental disorder and their impacts on clinical symptoms and intervention. Buletin Psikologi, 1, 8-18.

Baumrind, D. (1971). Current patterns of parental authority. Developmental Psychology Monographs, 4, 1-103.

Darling, N. (1998). Parenting style and its correlates. APA Parent News for JulyAugust 1999. Retrieved October 14, 2000, from the World Wide Web:http://www.athealth.com/practitio ner/ ceduc/parentingstyles.html

Garbarino, J., Kostelny, K. and Barry, F. (1997). Value transmission in an ecological context: The high-risk neigborhood. In J.E. Grusec and L. Kuczynski (Eds.) Parenting and children's internalization of values (pp. 307-332). New York: John Wiley \& Sons, Inc. 
Goodnow, J.J. (1997). Parenting and the transmission and internalization of values: From social-cultural perspectives to within-family analyses.In J.E. Grusec and L. Kuczynski (Eds.) Parenting and children's internalization of values (pp. 333-361). New York: John Wiley \& Sons, Inc.

Grusec, J.E. (1997). A history of research on parenting strategies and children's internalization of values. In J.E. Grusec and L. Kuczynski (Eds.) Parenting and children's internalization of values (pp. 3-22). New York: John Wiley \& Sons, Inc.

Johnson, R. (2002). Parenting style: A brief overview of various parenting. Parenting, Babies \& Toddlers. Retrieved September 12, 2002, from the http://www.psychpage.com.

Kuczynski, L. Marshall, S. and Schell. K. (1997). Value socialization in a bidirectional context. In J.E. Grusec and L. Kuczynski (Eds.) Parenting and children's internalization of values (pp. 23-52). New York: John Wiley \& Sons, Inc.

Lerner, R., Brennan, A.L., Noh, E.R., and Wilson, C. (1999). The parenting of adolescents as parents: A developmental contextual perspective. APA Parent News for July-August 1999. Retrieved October 14, 2000, from the World Wide Web: http://www.fww.org.articles/misc/0628 e.html.

Marzuki, L. (1995). Siri': Bagian kesadaran hukum rakyat Bugis-Makassar. Makassar: Hasanuddin University Press.

Matsumoto, D. (1996). Culture and psychology. California: Brooks/Cole Publishing Company.

Mattulada (1985). Latoa: Suatu lukisan analisis terhadap antropologi politik orang Bugis. Yogyakarta: Gadjah Mada University Press.

Niolon, R. (2002). The influence of parenting style on adolescent competence and substance use. Parent and Familuy Type. Retrieved September 12, 2002, from the http://www.psychpage.com.

Patterson, G.R. (1997). Performance models for parenting: A social interactional perspective. In J.E. Grusec and L. Kuczynski (Eds.) Parenting and children's internalization of values ( $\mathrm{pp}$. 193-226). New York: John Wiley \& Sons.

Reaves, A.L. (1999). Paternal practice, parental occupation and children's aggression. APA Parent News for JulyAugust 1999. Retrieved Oktober 14, 2000, from the World WideWeb:http://www.athealth.com//ce duc/ parentingstyles.html.

Thalib SB. 2007. Pengetahuan, sikap, dan keterampilan dalam pengasuhan berbasis budaya lokal. Laporan Penelitian. Kerjasama Unicef dan Pemda Sulawesi Selatan..

Webster-Stratton, C. (1998). Preventing conduct problems in head start children: Strengthening parenting competencies. Journal of Consulting and Clinical Psychology, 66, 715-730.

Wimbarti, S. (2000). Kecerdasan emosi: Apa dan bagaimana mengelolanya. Dalam S. Azwar (Ed.) Bunga rampai psikologi pendidikan (33-42). Yogyakarta: Pustaka Pelajar.

Wimbarti, S. (2001). Agar Indonesia tidak hanya dikenang di perpustakaan. Makalah Semiloka Nasional Yogyakarta: Konsorsium Fakultas Psikologi \& Himpsi DIY Bekerjasama Konrad Adenauer Stiftung. 